\title{
PEMBIAYAAN BAGI HASIL DAN FINANCING TO DEPOSIT RATIO (FDR) TERHADAP PROFITABILITAS BANK UMUM SYARIAH DI INDONESIA
}

\author{
Yana Fajriah \\ Program Studi Manajemen, STIEM Bongaya \\ Email: yana.fajriah@stiem-bongaya.ac.id \\ Edy Jumady \\ Program Studi Manajemen, STIEM Bongaya \\ Email: edy.jumady@stiem-bongaya.ac.id
}

\begin{abstract}
This study aims to determine whether production sharing financing and fianancing to deposit ratio affect profitability. Data collection used secondary data and sample in the study using purposive sampling technique. The population is all Islamic commercial banks in Indonesia, amounting to 14 Islamic commercial banks, while the sample taken is 5 Islamic commercial banks. The number of samples has been tested using the classical assumption test in the form of normality test, multicolonierity test, heteroscedasticity test. The data analysis method uses multiple linear regression analysis. The results showed that the first hypothesis proposed was rejected because it showed the results of the hypothesis test of profit-sharing financing which did not have a significant effect on profitability (ROA), while the second hypothesis is rejected because the results of hypothesis testing indicate that the financing to deposit ratio has no significant effect on profitability (ROA).
\end{abstract}

Keywords: Profit Sharing Financing, Financing to Deposit Ratio, Propability.

\begin{abstract}
Abstrak
Penelitian ini bertujuan untuk mengetahui apakah pembiayaan bagi hasil, financing to deposit ratio berpengaruh terhadap profitabilitas. Pengumpulan data menggunakan data sekunder dengan menggunakan teknik purposive sampel. Populasinya adalah seluruh Bank Umum Syariah di Indonesia yang berjumlah 14 Bank Umum Syariah sedangkan sampel yang di ambli adalah sebanyak 5 bank umum syariah. Jumlah sampel tersebut telah di uji menggunakan uji asumsi klasik berupa uji normalitas, uji multikolonieritas, serta metode analisis data menggunakan analisis regresi linier berganda. Hasil penelitian menunjukkan bahwa hipotesis pertama yang diajukan ditolak karena menunjukkan hasil uji hipotesis dari pembiayaan bagi hasil yang tidak berpengaruh signifikan terhadap
\end{abstract}




\section{4}

Yana Fajriah, Edy Jumady, PEMBIAYAAN BAGI HASIL DAN FINANCING TO DEPOSIT ......

profitabilitas (ROA), sedangkan hipotesis kedua diterima karena hasil uji hipotesis menunjukkan bahwa financing to deposit ratio berpengaruh signifikan terhadap profitabilitas (ROA).

Kata kunci: Pembiayaan Bagi Hasil, Financing to Deposit Ratio, Profitabilitas.

\section{Dasar Pemikiran}

Seiring pertumbuhan dan perkembangan bank syariah di Indonesia, kini perbankan syariah memiliki landasan kuat yang di atur dalam Undang-undang No. 21 tahun 2008 tentang perbankan syariah yang merupakan salah satu faktor penyebab perkembangan perbankan syariah di Indonesia semakin pesat. Namun bertambah banyak nya jumlah bank dan berbagai macam bentuk pelayanan dan produk yang diberikan dapat menciptakan permasalahan pada bank syariah itu sendiri. Menurut (Ibrahim et al, 2003 dalam Nizar, A. S., \& Anwar, M. K., 2015) permasalahan yang paling pokok yaitu bagaimana kualitas dari kinerja bank syariah. Menurut (Dendawijaya, 2009 dalam Nizar, A. S., \& Anwar, M. K., 2015) sebagai lembaga yang penting dalam perekonomian, perekonomian bank syariah membutuhkan adanya pengawasan kinerja keuangan yang baik oleh regulator perbankan (Jumady, 2020).

Tabel 1. Pertumbuhan Pembiayaan Bagi Hasil (PBH), Financing To Deposit Ratio (FDR), dan Return on Asset (ROA) Bank Umum Syariah 2015-2019.

\begin{tabular}{|c|c|c|c|c|}
\hline Tahun & $\begin{array}{c}\text { Pembiayaan Bagi } \\
\text { Hasil (PBH) } \\
\text { (Miliyar Rupiah) }\end{array}$ & $\begin{array}{c}\text { Pembiyaan Jual } \\
\text { Beli (PJB) } \\
\text { (Milyar Rupiah) }\end{array}$ & FDR (\%) & ROA \\
\hline 2015 & 55.886 & 97.076 & 88,03 & 0,49 \\
\hline 2016 & 62.151 & 114.009 & 85,99 & 0,63 \\
\hline 2017 & 67.535 & 120.028 & 79,61 & 0,63 \\
\hline 2018 & 74.541 & 125.044 & 78,53 & 1,28 \\
\hline 2019 & 90.423 & 132.046 & 77,91 & 1,73 \\
\hline
\end{tabular}

Sumber data: www.ojk.go.id

Berdasarkan tabel diatas variabel pembiayaan bagi hasil dan nilai Return On Asset (ROA) dari tahun 2015 hingga tahun 2019 mengalami peningkatan. Jika dilihat dari perhitungan ROA tahun 2015 yaitu sebesar 0,49\% dan tahun 2016 mengalami kenaikan sebesar 0,63\%. Pada tahun 2016 sampai dengan tahun 2017 ROA bank umum syariah P-ISSN : 2460-9595

E-ISSN : 2686-5149

DOI. 10.36908/isbank 
ISLAMIC BANKING: Jurnal Pemikiran dan Pengembangan Perbankan Syariah, Volume 6 Nomor 2 Edisi Februari 2021

stagnan pada angka 0,63\% Selanjutnya ROA ditahun 2017 hingga 2019 mengalami kenaikan yaitu dengan nilai ROA tahun 2017 sebesar 0,63\% di tahun 2018 sebesar 1,28\%, dan di tahun 2019 sebesar 1,73\%. Sedangkan nilai FDR dari tahun 2015 hingga tahun 2019 justru mengalami penurunan secara terus menerus.

Berdasarkan uraian perkembangan Pembiayaan Bagi Hasil, Financing to Deposit Ratio tersebut dapat dilihat bahwa masing-masing variabel mengalami pergerakan jumlah rata-rata dari tahun ketahun, dan terdapat penyimpangan dengan teori yang menunjukkan hubungan antara pembiayaan bagi hasil, serta Financing to Deposit Ratio (FDR) terhadap Return on Asset. Jika dilihat dari hubungan antara variabel FDR dengan variabel ROA, kedua variabel tersebut menunjukkan telah terjadi kesimpangan dengan teori dari penelitian (Sari, 2018) yang menyatakan bahwa semakin besar persentase FDR maka semakin besar pula tingkat persentase ROA. Penyimpangan tampak pada tahun 2015 ke tahun 2019, dimana FDR mengalami penurunan sedangkan ROA justru mengalami peningkatan.

Dilihat dari hubungan antara pembiayaan bagi hasil dengan ROA, kedua variabel tersebut menunjukkan telah terjadi kesimpangan. Indikasinya adalah, semakin tinggi jumlah pembiayaan bagi hasil maka semakin menurun pula persentase ROA. Namun tampak pada tahun 2016 hingga ke tahun 2019 pembiayaan bagi hasil dan nilai ROA sama-sama mengalami peningkatan.

Beberapa penelitian sebelumnya juga menunjukkan perbedaan antara peneliti satu dengan yang lainnya. Menurut Irmawati (2014) dan Budihariyanto, dkk. (2018) menyatakan bahwa pembiayaan bagi hasil berpengaruh positif terhadap profitabilitas, Sedangkan Saputri (2019) memperoleh hasil bahwa pembiayaan bagi hasil tidak berpengaruh terhadap profitabilitas. Selain itu (Riyadi, 2018) menyatakan bahwa Financing To Deposit ratio (FDR) berpengaruh terhadap profitabilitas (ROA). Sedangkan menurut Rizkika, R., Khairunnisa, K., \& Dillak, V. J. (2017) dalam penelitiannya menyatakan bahwa FDR tidak berpengaruh terhadap profitabilitas (ROA). 
236 | Yana Fajriah, Edy Jumady, PEMBIAYAAN BAGI HASIL daN FINANCING TO DEPOSIT ......

\section{Tinjauan Pustaka}

\section{Pembiayaan Bagi Hasil}

Menurut (Dahlan, 2012 dalam Sudarwati, 2018) pembiayaan (financing) merupakan istilah yang dipergunakan dalam bank syariah sebagaimana dalam bank konvensional disebut dengan kredit. Dalam kredit keuntungan berbasis pada bunga (interest based), sedangkan dalam pembiayaan (financing) berbasis pada keuntungan riil yang dikehendaki (margin) ataupun bagi hasil (profit sharing) (Hamzani, 2021). Pembiayaan menurut Muhammad (2002) adalah pendanaan yang diberikan oleh suatu pihak untuk mendukung investasi yang direncanakan. Pendanaan tersebut diadakan berdasar kesepakatan antar lembaga keuangan dan pihak peminjam untuk mengembalikan utangnya setelah jatuh tempo dengan imbalan atau bagi hasil (Rivai dalam purwanto, 2011).

Menurut (Dahla, 2012 dalam Sari, 2018) Jenis pembiayaan dengan transaksi bagi hasil didasarkan pada produk tersebut menggunakan prinsip bagi hasil dalam pembagian keuntungan. Transaksi bagi hasil juga dapat disebut dengan equity financing atau pembiayaan yang dalam pembagian keuntungannya didasarkan pada keadilan antara nasabah dengan bank. Keadilan tersebut tercermin dalam prinsip profit and loss sharing, rugi dibagi bersama dan rugi ditanggung bersama.

\section{Financing to Deposit Ratio (FDR)}

Menurut Dendawijaya (2009) bahwa Financing to Deposit Ratio (FDR) adalah ukuran seberapa jauh kemampuan bank dalam membiayai kembali penarikan dana yang dilakukan deposan dengan mengandalkan pembiayaan yang diberikan sebagai sumber likuiditasnya. Besarnya rasio likuiditas mengikuti perkembangan perekonomian nasional, sehingga sulit untuk menentukan berapa tingkat likuiditas yang ideal untuk suatu bank. Tingkat Likuiditas yang ideal berarti menunjukkan posisi likuiditas yang seimbang. Berdasarkan Surat Edaran Bank Indonesia No. 26/5/BPPP tanggal 29 Mei 1993, besarnya Financing To Deposit Ratio ditetapkan oleh Bank Indonesia tidak boleh melebihi $110 \%$ yang berarti bank boleh memberikan kredit atau pembiayaan melebihi jumlah dana pihak ketiga yang berhasil dihimpun asalkan tidak melebihi $110 \%$ 
(Muhammad dalam Irmawati, E. D., \& Prasetiono, P., 2014). FDR perbankan syariah yang melebihi batas akan menjadi ancaman serius bagi likuiditas bank Syariah itu sendiri.

\section{Profitabilitas}

Menurut (Mandum M. Hanafi, 2012), profitabilitas adalah rasio untuk mengukur kemampuan perusahaan untuk menghasilkan keuntungan pada tingkat penjualan, asset dan modal saham tertentu. Menurut (Kasmir, 2015), Profitabilitas adalah rasio untuk menilai kemampuan perusahaan untuk mencari keuntungan atau laba dalam satu periode tertentu. Rasio ini juga dapat memberikan ukura tingkat efektivitas manajemen perusahaan yang dapat di tunjukkan dari laba yang diperoleh dari penjualan atau dari pendapatan investasi. Rasio profitabilitas sering dipergunakan untuk mengetahui kemampuan perusahaan dalam menghasilkan laba. Dengan rasio profitabilitas ini, investor bisa mengetahui tingkat pengembalian investasi yang mereka tanamkan.

Salah satu cara untuk mengukur tingkat profitabilitas bank dalam penelitian ini yaitu dengan rasio rentabilitas dengan menggunakan Return On Asset (ROA). ROA merupakan rasio untuk megukur tingkat pengembalian dari bismis atas seluruh asset yang ada. Atau rasio ini menggambarkan efisiensi pada dana yang digunakan dalam perusahaan oleh karena itu, sering pula rasio ini disebut dengan Return on Investment (Sugiono, 2010).

\section{Metode Penelitian}

Penelitian ini menggunakan metode penelitian kuantitatif untuk mengetahui pengaruh pembiayaan bagi hasil dan FDR terhadap profitabilitas Bank Umum Syariah di Indonesia.

Populasi penelitian ini adalah seluruh bank umum syariah di Indonesia, saat ini terdapat 14 bank umum syariah di Indonesia sesuai dengan data yang dicantumkan statistik perbankan syariah dalam website www.ojk.go.id. populasi yang dapat menjadi 


\section{8 | Yana Fajriah, Edy Jumady, PEMBIAYAan BAGI hasiL daN FINANCING TO DepOSIT ......}

sampel dalam penelitian ini dengan tahap pengambilan keputusan sampel dapat dilihat pada tabel berikut.

Tabel 2

Tahap Pengambilan Sampel

\begin{tabular}{|c|l|c|}
\hline No & \multicolumn{1}{|c|}{ Populasi } & Julah BUS \\
\hline 1 & Bank Umum Syariah di Indonesia & 14 \\
\hline 2 & $\begin{array}{l}\text { Bank Umum Syariah yang menerbitkan laporan } \\
\text { keuangan triwulannya pada periode 2015-2019 }\end{array}$ & 14 \\
\hline 3 & Bank Umum Syariah yang terdaftar di BEI & 6 \\
\hline 4 & $\begin{array}{l}\text { Bank Umum Syariah yang memiliki kelengkapan data } \\
\text { terkait variabel yang diperlukan selama 2015-2019 }\end{array}$ & 3 \\
\hline 5 & Sampel & 5 \\
\hline 6 & Total sampel (5 Tahun X4 Triwulan x 5 Bank=100 ) & 100 \\
\hline
\end{tabular}

Sampel yang digunakan pada dalam penelitian ini adalah sebanyak 5 Bank Umum Syariah. Berdasarkan jumlah sampel, maka sampel yang digunakan dalam penelitian ini adalah:

1. Bank BRI Syariah

2. Bank Panin Dubai Syariah

3. Bank Victoria Syariah

4. Bank Bukopin Syariah

5. Bank BNI Syariah.

Teknik pengambilan sampel yang digunakan dalam penelitian yaitu purposive sampling. Kriteria yang digunakan untuk memilih sampel adalah sebagai berikut:

1. Bank Umum syariah di Indonesia 2015-2019

2. Bank Umum Syariah yang menerbitkan laporan keuangan triwulannya pada periode 2015-2019

3. Bank Umum Syariah yang terdaftar di Bursa Efek Indonesia

4. Bank Umum Syariah yang memiliki kelengkapan data terkait variabel yang diperlukan selama periode 2015-2019

\section{Definisi Operasional dan Pengukuran Variabel}


Definisi operasional variabel dalam penelitian ini adalah segala sesuatu yang telah ditetapkan peneliti untuk dipelajari sehingga diperoleh informasi tentang data penelitian tersebut. Penelitian ini merupakan penelitian kuantitatif yang berusaha mencari hubungan antara variabel independen dengan variabel dependen.

Adapun variabel-variabel yang digunakan dalam penelitian adalah:

Rasio profitabilitas merupakan rasio yang menggambarkan kemampuan perusahaan dalam menghasilkan laba melalui semua kemampuan dan sumber daya yang dimilikinya, yaitu berasal dari kegiatan penjualan, penggunaan aset maupun penggunaan modal (Hery dalam Irmawati 2014). rumus perhitungan ROA adalah sebagai berikut:

$$
\mathrm{ROA}=\frac{\text { Laba bersih }}{\text { Total Aset }} \times 100 \%
$$

Pembiayaan bagi hasil (X1) dalam penelitian ini merupakan penjumlahan antara prinsip mudharabah dan musyarakah. (Theresia dan Tenderlilin, 2007 dalam Irmawati, 2014) menjelaskan bahwa total pembiayaan bagi hasil diukur dengan logaritma natural. Penggunaan logaritma natural bertujuan agar hasilnya tidak menimbulkan bias, mengingat besarnya nilai pembiayaan bagi hasil antar bank syariah yang berbeda-beda. Selain itu, dimaksudkan agar data total pembiayaan bagi hasil dapat terdistribusi normal dan memiliki standar eror koefisien regresi minimal. Besarnya pembiayaan bagi hasil suatu bank dapat dihitung dengan rumus dibawah ini.

\section{Total Pembiayaan hagi Hasil = Ln ( Pembiayaan Prinsip Mudharabah+ Pembiayaan Prinsip Musyarakah)}

Financing to Depost Ratio (FDR) merupakan rasio yang menunjukkan kemampuan perusahaan dalam membayar hutangnya dan membayar kembali kepada deposannya, serta dapat memenuhi permintaan kredit. Rumus untuk menghitung rasio Financing to Depost Ratio (FDR) adalah (Muhammad, 2015)

$$
\mathrm{FDR}=\frac{\text { Total Pembiayaan }}{\text { Total Dana Pihak Ketiga }} \times 100 \%
$$

\section{Metode Analisis}




\section{0 | Yana Fajriah, Edy Jumady, PEMBIAYAan BAGI hasiL daN FINANCING TO DepOSIT ......}

Analisis data dalam penelitian ini mulanya dilakukan analisis statistik deskriptif untuk melihat trend data dari hasil pengumpulan data yang dilihat berdasarkan mean, nilai maksimal, nilai minimal, dan standar deviasi. Sedangkan alat analisis untuk melihat pengaruh variabel independen terhadap variabel dependen digunakan analisis regresi linier berganda.

$$
\mathbf{Y}=\mathbf{a}+\mathbf{b}_{1} \mathbf{X}_{1}+\mathbf{b}_{2} \mathbf{X}_{2}
$$

\section{Keterangan:}

$$
\begin{aligned}
& \mathrm{Y}=\text { Profitabilitas } \\
& \mathrm{X} 1=\text { Pembiayaan bagi hasil } \\
& \mathrm{X} 2=\text { Financing to Depost Ratio }
\end{aligned}
$$

\section{Pembahasan}

Statistik deskriptif pada penelitian ini digunakan untuk melihat data dari pembiayaan bagi hasil, financing to depost ratio dan laba bersih berdasarkan mean, nilai maksimal, nilai minimal, dan standar deviasi. Statistik pembiayaan bagi hasil, dan laba bersih adalah sebagai berikut:

Tabel 3. Descriptive statistic

\begin{tabular}{|l|r|r|r|r|r|}
\hline & $\mathrm{N}$ & $\begin{array}{c}\text { Minimu } \\
\mathrm{m}\end{array}$ & $\begin{array}{c}\text { Maximu } \\
\mathrm{m}\end{array}$ & \multicolumn{1}{c|}{ Mean } & $\begin{array}{c}\text { Std. } \\
\text { Deviation }\end{array}$ \\
\hline PBH & 100 & 12.48 & 16.28 & 14.9860 & 0.86890 \\
\hline FDR & 100 & 68.70 & 102.39 & 87.1025 & 7.34737 \\
\hline ROA & 100 & 0.02 & 1.97 & 0.6939 & 0.53940 \\
\hline $\begin{array}{l}\text { Valid N } \\
\text { (listwise) }\end{array}$ & 100 & & & & \\
\hline
\end{tabular}

Sumber: Olah Data SPSS 2020

Pada penelitian ini variabel independen adalah pembiayaan bagi hasil (X1), financing to deposit ratio (X2), dan variabel dependennya adalah profitabilitas/ROA (Y). Rata rata dari pembiayaan jual bagi hasil dengan nilai 14.9860 , financing to deposit ratio dengan nilai 87.1025, dan nilai rata rata Return on Aset 0.6939. 
Tabel 4 Uji Normalitas

\begin{tabular}{|l|l|r|}
\hline \multicolumn{2}{|c|}{ One-Sample Kolmogorov-Smirnov Test } \\
\hline \multicolumn{2}{|l|}{} & $\begin{array}{c}\text { Unstandardized } \\
\text { Residual }\end{array}$ \\
\hline $\mathrm{N}$ & Mean & 0.0000000 \\
\hline $\begin{array}{l}\text { Normal } \\
\text { Parameters }\end{array}$ & $\begin{array}{l}\text { Std. } \\
\text { Deviation }\end{array}$ \\
\hline $\begin{array}{l}\text { Most } \\
\text { Extreme } \\
\text { Differences }\end{array}$ & Absolute & 0.40233006 \\
\cline { 2 - 3 } & Positive & 0.053 \\
\cline { 2 - 3 } Test Statistic & Negative & 0.053 \\
\hline Asymp. Sig. (2-tailed) & -0.035 \\
\hline \multicolumn{2}{|l|}{ Sumber: Olah Data SPSS 2020 } & 0.053 \\
\hline
\end{tabular}

Dari tabel 4 diketahui bahwa hasil uji normalitas diperoleh nilai Asymp sig 0, 200 $>0,05$ sehingga dapat dikatakan bahwa data terdistribusi normal.

Tabel 5. Uji Multikolonieritas

\begin{tabular}{|c|c|c|c|}
\hline \multicolumn{4}{|c|}{ Coefficients ${ }^{\mathrm{a}}$} \\
\hline & \multirow[b]{2}{*}{ Model } & \multicolumn{2}{|c|}{$\begin{array}{c}\text { Collinearity } \\
\text { Statistics }\end{array}$} \\
\hline & & Tolerance & VIF \\
\hline \multirow[t]{2}{*}{1} & $\mathrm{PBH}$ & 0.651 & 1.537 \\
\hline & FDR & 0.777 & 1.287 \\
\hline & & & \\
\hline
\end{tabular}

Sumber: Olah Data SPSS 2020

Dari tabel hasil uji Multikolonieritas dapat disimpulkan bahwa nilai variabel PBH dan FDR tidak terjadi Multikolonieritas karena nilai VIF PBH sebesar 1, 537 dan nilai tolerance sebesar 0.651 sama halnya dengan variabel FDR yang mendapatkan hasil VIF sebesar 1.287 dan nilai tolerance sebesar 0, 777. Seluruh variabel menunjukkam nilai VIF $<10$ dan nilai Tolerance $>0,1$. 


\section{2 | Yana Fajriah, Edy Jumady, PEMBIAYAan BAGI HASIL DAN FINANCING TO DePOSIT ......}

\section{Regresi Linier Berganda}

Analisis regresi linier berganda digunakan untuk menganalisa data yang bersifat multivariate. Analisis ini digunakan untuk meramalkan nilai variabel dependen (Y), dengan variabel independen yang lebih dari satu (Bawono, 2006 dalam Saputri 2018). Analisis regresi berganda digunakan untuk mengetahui seberapa besar pengaruh $\mathrm{PBH}$ (X1), FDR (X2) terhadap profitabilitas (ROA) bank umum syariah (Y).

\section{Tabel 6 Uji Analisis Regresi Linier Berganda}

\begin{tabular}{|c|c|c|c|c|c|}
\hline \multirow[b]{2}{*}{ Model } & \multicolumn{3}{|r|}{$\begin{array}{l}\text { Standardize } \\
\mathrm{d} \\
\text { Coefficients }\end{array}$} & \multirow[b]{2}{*}{$\mathrm{t}$} & \multirow[b]{2}{*}{ Sig. } \\
\hline & B & $\begin{array}{l}\text { Std. } \\
\text { Error }\end{array}$ & Beta & & \\
\hline $\begin{array}{ll}1 \text { (Constant } \\
\end{array}$ & -4.263 & 1.058 & & $4.030^{-}$ & 0.000 \\
\hline PBH & 0.035 & 0.059 & 0.056 & 0.590 & 0.556 \\
\hline FDR & 0.254 & 0.031 & 0.690 & 2.040 & 0.048 \\
\hline
\end{tabular}

Berdasarkan data tabel 6 dapat diketahui nilai koefisien PBH (X1), dan FDR (X2) terhadap ROA (Y) sebesar 0,035 (X1), 0,254 (X2) dan nilai konstanta sebesar $-4,263$. Dengan demikian terbentuk persamaan regresi sebagai berikut:

$$
\begin{gathered}
\mathbf{Y}=\mathbf{a}+\mathbf{b}_{1} \mathbf{X}_{\mathbf{1}}+\mathbf{b}_{\mathbf{2}} \mathbf{X}_{\mathbf{2}} \\
\mathrm{Y}=-4,263+0,035 \mathrm{X} 1+0,254 \mathrm{X} 2
\end{gathered}
$$

Persamaan regresi diatas dapat disimpulkan sebagai berikut:

Pada tabel coefficient diatas diperoleh nilai $\mathrm{t}$ hitung untuk variabel PBH sebesar 0,590 dengan sig sebesar 0,556 . Pada $\alpha=5 \%$ (karena pengujian dua sisi sehingga 0,025 ) maka diperoleh nilai derajat kebebasan (df) n-k-1 atau 100-3-1=96 (dimana k merupakan jumlah variabel independen). Dengan nilai df sebesar 100 maka diperoleh nilai $t_{\text {tabel }}$


dana PBH tidak berpengaruh signifikan terhadap profitabilitas (ROA). Sedangkan nilai $\mathrm{t}_{\text {hitung }}$ untuk variabel FDR sebesar 2,040 nilainya lebih besar dengan $\mathrm{t}_{\text {tabel }}$ 1,984 atau nilai sig $0,048<$ dari 0,05 , maka dapat disimpukan bahwa FDR berpengaruh signifikan terhadap profitabilitas (ROA). 
Kemudian hasil uji $\mathrm{F}$ tabel anova dieroleh nilai $\mathrm{F}_{\text {hitung }}$ sebesar 25,517 dengan nilai sig sebesar 0,000 pada $\alpha=5 \%$ dengan derajta kebebasan $\left(\mathrm{df}_{1}\right)$ sebesar 2 dan derajat kebebasan $\left(\mathrm{df}_{2}\right)$ sebesar $\mathrm{n}-\mathrm{k}-1$ atau $100-3-1=96$ (k merupakan jumlah variabel independen dan $\mathrm{n}$ adalah jumlah sampel), sehingga nilai $\mathrm{F}_{\text {tabel }}$ diperoleh sebesar 3,09.


pengaruh pembiayaan bagi hasil, Financing to deposit ratio (FDR) secara bersama sama berpengaruh terhadap profitabilitas.

Diketahui nilai koefisien determinasi R Square adalah sebesar 0,444. Nilai R square 0,443 ini berasal dari pengkuadratan nilai koefisien korelasi 0,666 atau " $R$ ", yaitu 0,666 $\times 0,666=0,443$. Besarnya angka koefisien determinasi ( $\mathrm{R}$ square) adalah 0,443 atau dama dengan 44,3\%. Angka tersebut mengandung arti bahwa variabel pembiayaan bagi hasil (X1), financing to deposit ratio (X2) secara simultan (bersama-sama) berpengaruh terhadap variabel prestasi (Y) sebesar 44,3\% . Sedangkan sisinya $(100 \%-44,3 \%=56 \%)$ dipengaruhi oleh variabel lain diluar persamaan regresi ini atau variabel yang tidak diteliti. Korelasi pembiayaan bagi hasil, financing to deposit ratio terhadap y dapat dikatan kuat karena Jika nilai $\mathrm{R}^{2}$ semakin mendekati 1 maka model yang diusulkan dikatakan baik.

Dari Hasil Uji analisis data pembiayaan bagi hasil, financing to depost ratio terhadap profitabilitas (ROA) pada Bank Umum Syariah yang terdaftar di BEI periode 2015-2019 yang telah diuraikan sebelumnya maka dapat disimpulkan sebagai berikut:

1) Pengaruh Pembiayaan Bagi Hasil (PBH) terhadap profitabilitas (ROA)

Hasil uji statistic variabel pembiayaan bagi hasil (X1) diperoleh nilai thitung 0,590 lebih kecil dari $t_{\text {tabel }}$ sebesar 1,984 dan nilai sig 0,556 lebih besar dari nilai alfa 0,05. Sehingga dapat dikatakan dana PBH tidak berpengaruh terhadap profitabilitas (ROA). Dengan demikian secara empiris menolak hipotesis pertama (H1), yang menyatakan bahwa pembiayaan bagi hasil berpengaruh signifikan terhadap profitabilitas (ROA). Hal ini berarti bahwa semakin tinggi pembiayaan bagi hasil maka ROA akan semakin menurun. Hasil penelitian ini diperkuat oleh (Nurpitasari, 2020; Azhar, I., \& Nasim, A., 2016) 


\section{4 | Yana Fajriah, Edy Jumady, PEMBIAYAan BAGI hasiL daN fINANCING TO Deposit ......}

Bagi dunia perbankan pembiayaan merupakan unsur utama untuk memperoleh keuntungan. Artinya besarnya laba suatu bank sangatlah dipengaruhi dari jumlah pembiayaan yang disalurkan dalam suatu periode. Semakin banyak pembiayaan yang disalurkan bank kepada masyarakat, maka semakin besar pula perolehan laba dari bidang pembiayaan ini. Hasil penelitian ini menunjukkan bahwa pembiayaan bagi hasil berpengaruh negatif signifikan terhadap ROA. Sehingga dapat dinyatakan bahwa semakin tinggi nilai pembiayaan bagi hasil maka akan semakin menurunkan tingkat ROA. Hal ini terjadi karena disebabkan oleh kepercayaan yang disalahgunakan oleh nasabah. Bank Syariah mempercayakan dananya kepada nasabah melalui penyaluran pembiayaan untuk dikelola dan nantinya akan dikembalikan sesuai kesepakatan yang dibuat. Namun, terdapat kemungkinan jika nasabah akan menyalahgunakan kepercayaan dari pihak Bank Syariah, sehingga belum tentu pembiayaan bagi hasil yang disalurkan oleh bank pada nasabah akan dikembalikan sesuai perjanjian yang telah disepakati bersama antara bank dengan nasabah, sehingga hal tersebut dapat menurunkan tingkat laba suatu bank.

2) Pengaruh Financing to Deposit Ratio (FDR) terhadap profitabilitas (ROA).

Hasil Uji statistic variabel FDR (X2) diperoleh nilai thitung sebesar 1,984 sama dengan nilai $t_{\text {tabel }}$ sebesar 1,984 dan nilai sig 0,050 lebih besar dari 0,05, maka dapat disimpulkan bahwa FDR tidak berpengaruh signifikan terhadap profitabilitas (ROA). Dengan demikian Hipotesis ketiga (H3) ditolak. Hal ini berarti semakin besar FDR maka akan semakin menurun nilai profitabilitasnya (ROA). Hasil uji simultan (uji F) pembiayaan bagi hasil $(\mathrm{PBH})$ dan financing to deposit ratio (FDR) yaitu nilai $F_{\text {hitung }}$ sebesar 25,517 lebih besar dari nilai $\mathrm{F}_{\text {tabel }}$ 3,09 atau nilai sig 0,000 lebih kecil dari alfa 0,05 maka. Artinya pengaruh PBH, PJB, FDR secara bersama sama berpengaruh terhadap profitabilitas.

Untuk hasil koefisien detrminasi diperoleh nila $R$ square " $\mathrm{R}$ " " sebesar 0,444 . Nilai R square 0,443 ini berasal dari pengkuadratan nilai koefisien korelasi 0,666 atau " $R$ ", yaitu $0,666 \times 0,666=0,443$. Besarnya angka koefisien determinasi ( $R$ square) adalah 0,443 atau dama dengan 44,3\%. Angka tersebut mengandung arti bahwa variabel 
pembiayaan bagi hasil (X1), financing to deposit ratio (X2) secara simultan (bersamasama) berpengaruh terhadap variabel prestasi (Y) sebesar 44,3\% . Sedangkan sisinya $(100 \%-44,3 \%=56 \%)$ dipengaruhi oleh variabel lain diluar persamaan regresi ini atau variabel yang tidak diteliti. Hasil analisis ini mendukung penelitian dari Rizkika, R.,

Khairunnisa, K., \& Dillak, V. J. (2017) dan Almunawwaroh, M., \& Marliana, R. (2018).

\section{Simpulan}

1) Untuk hasil penelitian pembiayaan bagi hasil menujukkan hasil bahwa variabel tersebut tidak berpengaruh signifikan terhadap profitabilitas (ROA). Yang demikian menolak hipotesis pertama yang menyatakan bahwa pembiayaan bagi hasil berpengaruh signifikan terhadap profitabilitas. Hal ini berarti semakin tinggi PBH makan profitabilitas bank pun juga akan menurun, penyebabnya yaitu pembiayaan bagi hasil yang dihasilkan Bank terlalu minim, ini juga dikarenakan usaha yang dijalankan oleh nasabah bank tidak berjalan dengan lancar atau mengalami kerugian yang juga berpengaruh terhadap pendapatan laba dari pembiayaan bagi hasil.

2) Untuk hasil uji statistic dari financing to deposit ratio (FDR) mendapatkan hasil bahwa variabel tersebut tidak berpengaruh seignifikan terhadap profitabilitas (ROA). Hal ini menandakan bahwa semakin tinggi FDR maka tingkat profitabilitas ROA juga menurun karena jiika bank terlalu banyak menyalurkan kredit kepada nasabah maka kredit macet juga akan menanti di masa mendatang. 


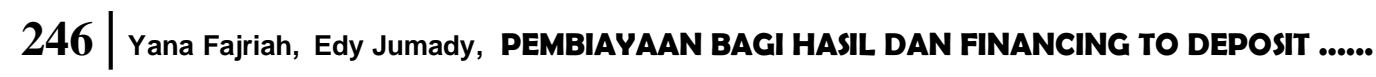

DAFTAR PUSTAKA

Almunawwaroh, M., \& Marliana, R. (2018). Pengaruh CAR, NPF dan FDR terhadap profitabilitas bank syariah di Indonesia. Amwaluna: Jurnal Ekonomi Dan Keuangan Syariah, 2(1), 1-17.

Azhar, I., \& Nasim, A. (2016). Pengaruh Pembiayaan Jual Beli, Pembiayaan Bagi Hasil, Dan Non Performing Finance Terhadap Profitabilitas (Studi Kasus Pada Bank Umum Syariah Di Indonesia Periode 2012-2014). Jurnal Aset (Akuntansi Riset), 8(1), 61-76.

Budihariyanto, dkk. (2018). Pengaruh Pembiayaan (Bagi hasil dan jual beli), Financing to Deposit Ratio (FDR), dan Non Performing Financing (NPF) Terhadap profitabilitas Pada Bank Umum Syariah Yang Terdaftar di Bursa Efek Indonesia Periode Tahun 2015-2017. Jurnal Akuntasi dan Keuangan. 4(1).

Dendawijaya, Lukman. (2009). Manajemen Perbankan. Jakarta: Ghalia Indonesia.

Hanafi, Mamduh M. dan Abdul Halim. (2012). Analisis Laporan Keuangan. Yogyakarta: UPP STIM YKPN.

Irmawati, E. D., \& PRASETIONO, P. (2014). Pengaruh FDR, Pembiayaan Jual Beli, Pembiayaan Bagi Hasil, Pembiayaan Sewa Menyewa, dan NPF terhadap Profitabilitas (Studi pada Bank Umum Syariah di Indonesia Periode Tahun 2009-2013) Doctoral dissertation, Fakultas Ekonomika dan Bisnis.

Ismail. (2011). Perbankan Syariah. Jakarta: Kencana Prenadamedia Group

Hamzani, H. A. A. I. (2021). Etika Perbankan Syariah: Teori dan Implementasi.

Deepublish.

Jumady, E. (2020). Peran Moderasi Disiplin Kerja Pada Pengaruh Kepemimpinan Terhadap Produktivitas Kerja Karyawan Perbankan Syariah Di Makassar. Islamic Banking: Jurnal Pemikiran Dan Pengembangan Perbankan Syariah, 5(2), 1-20.

Jumady, E., Pattiware, A., Utami, M., \& Ishak, R. (2017). Hubungan Antara Profitabilitas Dan Leverage Dengan Stock Return Pada Industri Manufaktur Dibursa Efek Indonesia. Jurnal Ilmiah Bongaya, 25-32.

Kasmir. (2015). Analisis Laporan Keuangan. Edisi Satu. Jakarta: PT RajaGrafindo Persada.

Nizar, A. S., \& Anwar, M. K. (2015). Pengaruh pembiayaan jual beli, pembiayaan bagi hasil dan intellectual capital terhadap kinerja keuangan bank syariah. Aktual: Jurnal Akuntansi, 6(2), 130-146.

Rapanna, P., \& Jumady, E. (2020). The Impact of Corona Virus Outbreak Regarding the Large-Scale Social Restriction Policy on Economic Attitudes in Makassar. Int'l J. Soc. Sci. Stud., 8, 83. 
Putriani, Arifi, Tisa dan Farida, Alimatul. (2019). Pengaruh Dana Pihak Ketiga Dan Pembiayaan Terhadap Profitabilitas Bank Umum Syariah Di Indonesia Periode 2014-2018. Jurnal Ekonomi Islam. 11(1).

Riyadi, Slamet dan Yulianto, Agung. (2014). Pengaruh Pembiayaan Bagi Hasil, Pembiayaan Jual Beli, Financing To Deposit Ratio (Fdr) Dan Non Performing Financing (NPF) Terhadap Profitabilitas Bank Umum Syariah Di Indonesia. Accounting Analysis Journal. 3(4)

Rizkika, R., Khairunnisa, K., \& Dillak, V. J. (2017). Analisis Faktor-Faktor Yang Mempengaruhi Profitabilitas Bank Umum Syariah di Indonesia (Studi Pada Bank Umum Syariah Yang Terdaftar di Otoritas Jasa Keuangan Selama Tahun 2012-2015). eProceedings of Management, 4(3).

Saputri, Dewi, Febriana. (2018). Pengaruh Pembiayaan Bagi Hasil , dan Pembiayaan Jual Beli Terhadap Laba Bersih. Skripsi.Porogo: Universitas Institut agama islam ponorogo.

Sari, D. W., \& MAHFUD, M. K. (2013). Pengaruh Pembiayaan Jual Beli, Pembiayaan Bagi Hasil, Financing To Deposit Ratio, dan Non Performing Financing terhadap Profitabilitas Bank Umum Syariah di Indonesia Periode 20092012 Doctoral dissertation, Fakultas Ekonomika dan Bisnis.

Sari. Kurnia. (2018). Pengaruh Pembiayaan Murabahah, Capital Adequacy Ratio (Car), Financing To Deposit Ratio (Fdr), Dan Inflasi Terhadap Profitabilitas (Roa) Dengan Non Performing Financing (Npf) Sebagai Variabel Intervening Pada Bank Umum Syariah (Periode 2013-2017). Skripsi. Salatiga: Institut Agama Islam Negeri.

Sudarwati, L. (2020). Pengaruh Pembiayaan Bagi Hasil Dan Pembiayaan Jual Beli Terhadap Profitabilitas (Roa) Dengan Non Performing Financing (Npf) Sebagai Variabel Intervening (Studi Kasus Pada Bank Umum Syariah Periode 20132017) Doctoral dissertation, IAIN SALATIGA.

Sudarwati. Lilis. (2018). Pengaruh Pembiayaan Bagi Hasil Dan Pembiayaan Jual Beli Terhadap Profitabilitas (Roa) Dengan Non Performing Financing (Npf) Sebagai Variabel Intervening. Skripsi. Salatiga: Institut Agama Islam Negeri

Sugiono, Arief. (2010). Manajemen Keuangan Untuk Praktisi Keuangan. Jakarta: PT Grasindo, anggota Ikapi. 
248 | Yana Fajriah, Edy Jumady, PEMBIAYAAN BAGI HASIL daN FINANCING TO DEPOSIT ...... 